\title{
Assessment of Undiscovered Oil and Gas Resources of the Timan-Pechora Basin Province, Russia, 2008
}

Using a geology-based assessment methodology, the U.S. Geological Survey (USGS) estimated means of 1.6 billion barrels of undiscovered oil and 9 trillion cubic feet of natural gas north of the Arctic Circle in the TimanPechora Basin Province of Russia.

\section{Introduction}

The U.S. Geological Survey (USGS) recently assessed the undiscovered oil and gas potential of the Timan-Pechora Basin Province in Russia as part of the USGS Circum-Arctic Oil and Gas Resource Appraisal program. Geologically, the Timan-Pechora Basin Province is a triangular-shaped cratonic block bounded by the northeast-southwest trending Ural Mountains and the northwest-southeast trending Timan Ridge. The northern boundary is shared with the South Barents Sea Province (fig. 1). The Timan-Pechora Basin Province has a long history of oil and gas exploration and production. The first field was discovered in 1930 and, after 75 years of exploration, more than 230 fields have been discovered and more than 5,400 wells have been drilled. This has resulted in the discovery of more than 16 billion barrels of oil and 40 trillion cubic feet of gas.

Several studies have presented geological summaries of the Timan-Pechora Basin Province and the potential for its remaining oil and gas resources (for example, Ulmishek, 1982; Lindquist, 1999; Ulmishek, 2000). This report summarizes a reassessment of the undiscovered oil and gas potential of the province, as the last assessment was completed in 2000 (Ulmishek, 2000). The total petroleum system and three assessment units defined by the USGS for the assessment in 2000 were adopted for this reassessment.

\section{Geologic Definition of Assessment Units}

The USGS defined the Domanik-Paleozoic Total Petroleum System in the Timan-Pechora Basin Province. Several petroleum source rocks are postulated to be present, including source rocks in Ordovician, Silurian, Devonian, Carboniferous, and Permian strata; of these, the Middle Devonian Domanik Formation is the most important petroleum source rock.

Three assessment units (AU) were defined geologically and encompass the foredeep and platform areas of the province (fig. 2). The Northwest Izhma Depression AU (fig. 1) is defined to include potential reservoirs within the northwestern part of the province, where reservoir rocks and source rocks mainly range from thin to absent on the platform; this AU was not quantitatively assessed. The Main Basin Platform AU (fig. 1) encompasses all traps and reservoirs in the central part of the province, an area that is characterized by a complex tectonic and structural history. The Foredeep Basins AU (fig. 1) is defined to include

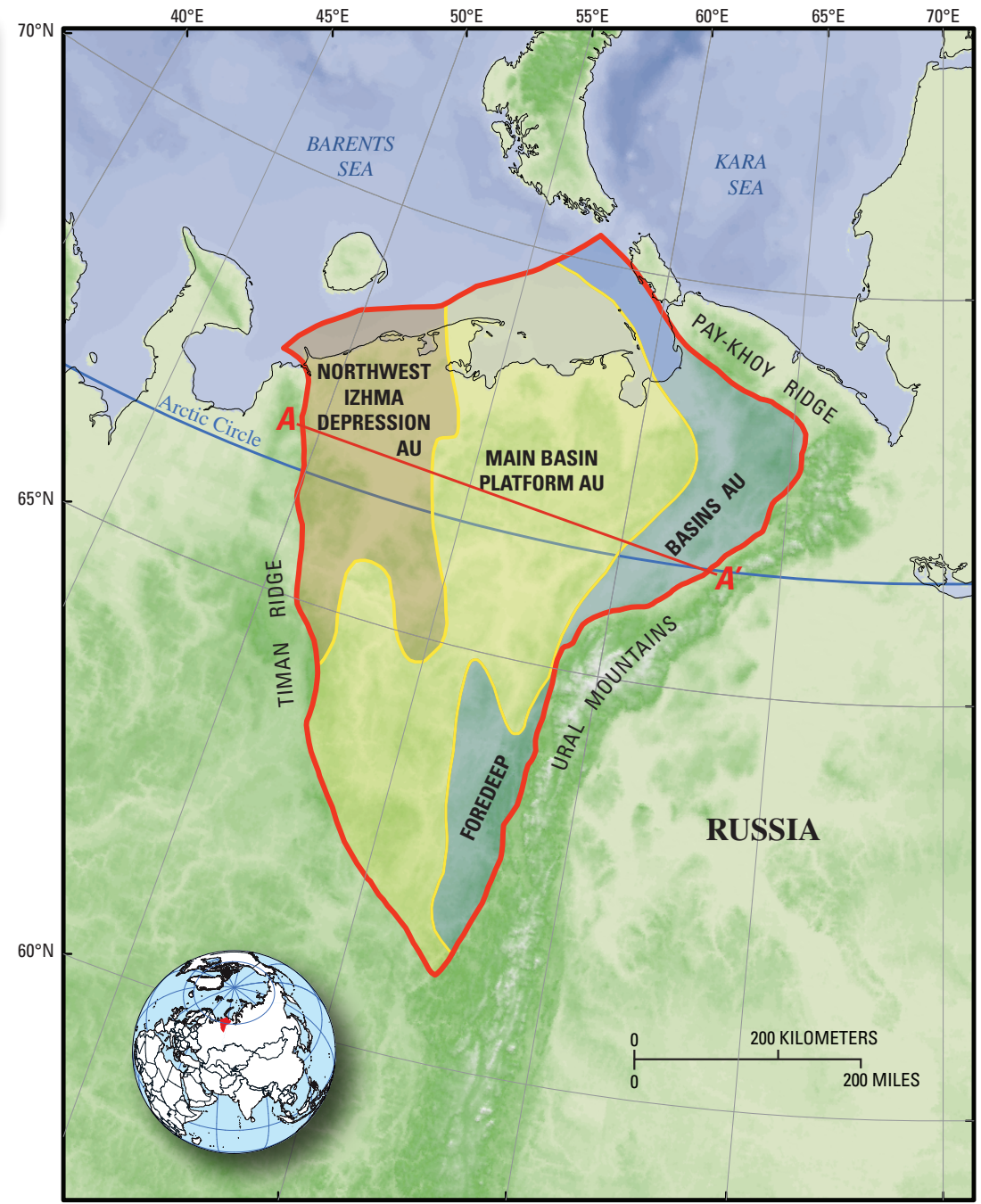

Figure 1. Timan-Pechora Basin Province of Russia (red line). Three assessment units (AU; yellow lines) were defined in this study: Northwest Izhama Depression $\mathrm{AU}$, Main Platform Basin AU, Foredeep Basins AU. Note that portions of each $\mathrm{AU}$ extend south of the Arctic Circle. $A-A^{\prime}$, line of section in figure 2.

reservoirs and traps within the foredeep basins of the Ural orogenic belt in the eastern part of the province. Each of the latter two AUs was evaluated in its entirety for undiscovered, technically recoverable oil and gas resources, but the assessment results reported here (table 1) are only for those portions of each AU that are north of the Arctic Circle.

\section{Resource Summary}

The estimated means for conventional resources in portions of the Main Basin Platform AU and Foredep Basins AU north of the Arctic Circle are 1,668 million barrels of oil (MMBO), 9,062 billion cubic feet of natural gas 


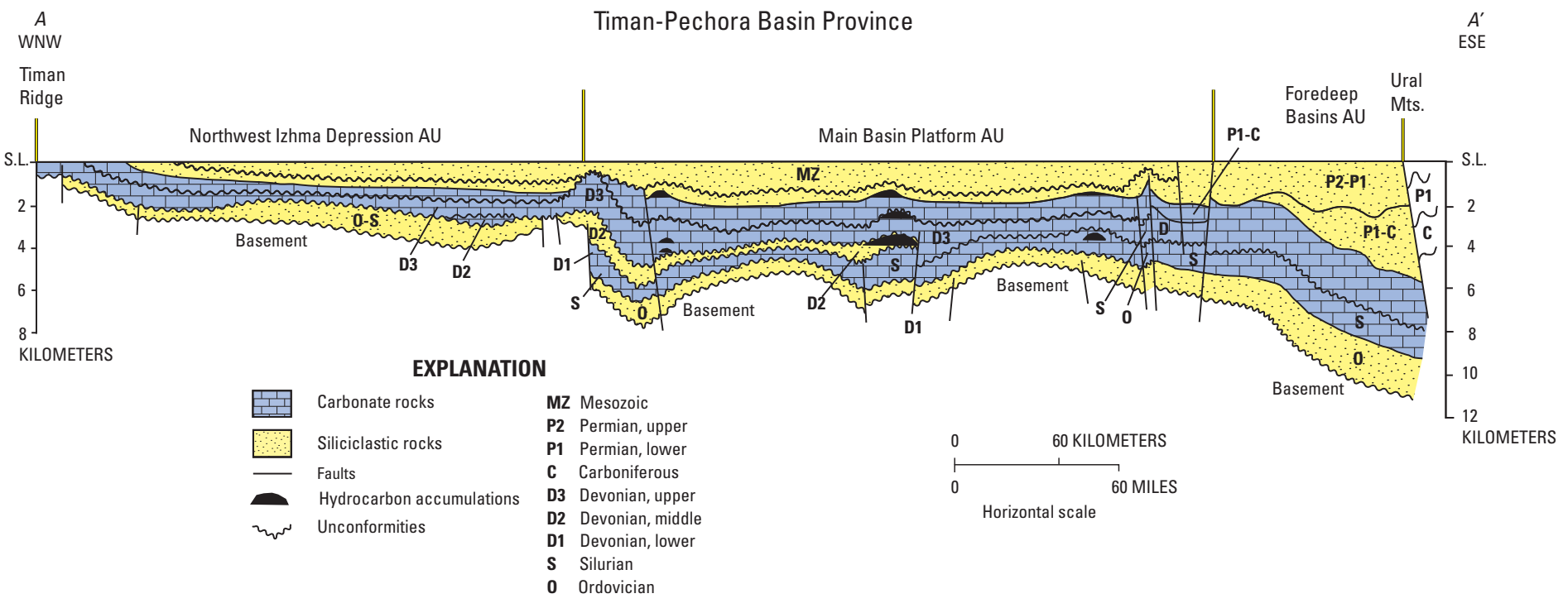

Figure 2. Generalized structure cross section of the Timan-Pechora Basin Province. Location of section shown in figure 1. From Lindquist (1999).

(BCFG), and 204 million barrels of natural-gas liquids (MMBNGL) (table 1). Nearly all of the undiscovered conventional oil resources are estimated to be in the Main Basin Platform AU, and 60 percent of the nonassociated gas is estimated to be in the Foredeep Basins AU. Volumes of gas potentially in a basin-centered gas accumulation in the Foredeep Basins AU were not assessed.

\section{References}

Lindquist, S.J., 1999, The Timan-Pechora Basin Province of northwest Arctic Russia: Domanik-Paleozoic Total Petroleum System: U.S. Geological Survey Open-File Report 99-50-G, 40 p.

Ulmishek, G., 1982, Petroleum geology and resource assessment of the Timan-Pechora Basin, USSR, and the adjacent Barents-northern Kara Shelf: Argonne, Illinois, Argonne National Laboratory, Energy and Environmental Systems Division, Report ANL/EES-TM-199, $197 \mathrm{p}$.
Ulmishek, G., 2000, Timan-Pechora Basin: Geologic Province 1008, in U.S. Geological Survey World Energy Assessment Team, U.S. Geological Survey World Petroleum Assessment 2000-description and results: U.S. Geological Survey Digital Data Series DDS-60, four CD-ROM set, Disk 2.

\section{For Further Information}

Assessment results are available at the USGS Energy Program website, http://energy.usgs.gov/arctic, or contact Donald L. Gautier, Task Leader for the USGS Circum-Arctic Oil and Gas Resource Appraisal (gautier@usgs.gov).

Timan-Pechora Basin Province Assessment Team: Christopher J. Schenk, Kenneth J. Bird, Ronald R. Charpentier, Donald L. Gautier, David W. Houseknecht, Timothy R. Klett, Thomas Moore, Mark J. Pawlewicz, Janet Pitman, and Marilyn E. Tennyson.

Table 1. Timan-Pechora Basin Province assessment results, north of the Arctic Circle.

[MMB0, million barrels of oil. BCFG, billion cubic feet of gas. MMBNGL, million barrels of natural gas liquids. Results shown are fully risked estimates. For gas accumulations, all liquids are included as NGL (natural gas liquids). Undiscovered gas resources are the sum of nonassociated and associated gas. F95 represents a 95 percent chance of at least the amount tabulated; other fractiles are defined similarly. AU probability is the chance of at least one accumulation of minimum size within the AU. TPS, total petroleum system; $\mathrm{AU}$, assessment unit. Gray shading indicates not applicable]

\begin{tabular}{|c|c|c|c|c|c|c|c|c|c|c|c|c|c|c|c|}
\hline \multirow{3}{*}{$\begin{array}{l}\text { Total Petroleum Systems } \\
\text { (TPS) } \\
\text { and Assessment Units (AU) }\end{array}$} & \multirow{3}{*}{$\begin{array}{l}\text { AU } \\
\text { Prob- } \\
\text { ability }\end{array}$} & \multirow{3}{*}{$\begin{array}{l}\text { Field } \\
\text { Type }\end{array}$} & \multirow{3}{*}{\begin{tabular}{|c|} 
Largest \\
Expected \\
Field \\
Size \\
\end{tabular}} & \multicolumn{12}{|c|}{ Total Undiscovered Resources } \\
\hline & & & & \multicolumn{4}{|c|}{ Oil (MMBO) } & \multicolumn{4}{|c|}{ Gas (BCFG) } & \multicolumn{4}{|c|}{ NGL (MMBNGL) } \\
\hline & & & & F95 & F50 & F5 & Mean & F95 & $\mathrm{F} 50$ & F5 & Mean & F95 & $\mathrm{F} 50$ & F5 & Mean \\
\hline \multicolumn{16}{|l|}{ Domanik-Paleozoic TPS } \\
\hline $\begin{array}{l}\text { Northwest Izhma } \\
\text { Depression AU }\end{array}$ & 0.02 & & & \multicolumn{12}{|c|}{ Not quantitatively assessed } \\
\hline \multirow{2}{*}{ Main Basin Platform AU } & \multirow{2}{*}{1.0} & Oil & 549 & 762 & 1,504 & 2,852 & 1,613 & 918 & 1,942 & 3,975 & 2,131 & 20 & 45 & 95 & 50 \\
\hline & & Gas & 1,404 & & & & & 895 & 2,476 & 6,143 & 2,859 & 19 & 54 & 190 & 64 \\
\hline \multirow{2}{*}{ Foredeep Basins AU } & \multirow{2}{*}{0.54} & Oil & 163 & 0 & 0 & 234 & 55 & 0 & 0 & 327 & 72 & 0 & 0 & 7 & 2 \\
\hline & & Gas & 1,946 & & & & & 0 & 3,658 & 12,094 & 4,000 & 0 & 74 & 272 & 88 \\
\hline $\begin{array}{l}\text { Total Conventional } \\
\text { Resources }\end{array}$ & & & & & & & 1,668 & & & & 9,062 & & & & 204 \\
\hline
\end{tabular}

